\title{
TEXHИЧECRИE HAYRИ
}

VARIANTS OF GRINDING DISCS WITH SPATIAL LOCATION OF KNIVES

\author{
Tikhonov Ilya Sergeevich \\ post graduate student \\ Reshetnev Siberian State University of Science and Technology \\ Krasnoyarsk \\ Kozhukhov Viktor Anatol'evich \\ candidate of technical sciences, associate professor \\ Reshetnev Siberian State University of Science and Technology \\ Krasnoyarsk \\ Alashkevich Yurij Davydovich \\ doctor of technical sciences, professor \\ Reshetnev Siberian State University of Science and Technology \\ Krasnoyarsk
}

\section{ВАРИАНТЫ ГАРНИТУРЫ С ПРОСТРАНСТВЕННЫМ РАСПОЛОЖЕНИЕМ НОЖЕЙ}

\author{
Тихонов Илья Сергеевич \\ аспирант \\ Сибирский государственный университет науки и технологий имени академика \\ М.Ф. Решетнева \\ Красноярск \\ Кожухов Виктор Анатольевич \\ кандидат технических наук, доцент \\ Сибирский государственный университет науки и технологий имени академика \\ М.Ф. Решетнева \\ Красноярск \\ Алешкевич Юрий Давыдович \\ доктор технических наук, профессор \\ Сибирский государственный университет науки и технологий имени академика \\ М.Ф. Решетнева \\ Красноярск \\ DOI: $\underline{10.31618 / E S U .2413-9335.2020 .2 .75 .829}$
} knives.

ANNOTATION

This article presents an example of the profile view of a knife grinding set with a spatial arrangement of

\section{АННОТАЦИЯ}

В данной статье представляются пример вида профиля ножевой размалывающей гарнитуры с пространственным расположением ножей.

Keywords: Knife set, spatial arrangement of knives, grinding

Ключевые слова: Ножевая гарнитура, пространственное расположение ножей, размол

In the pulp and paper industry, fibrous materials are produced in knife-breeding machines, in conical and disk mills. There are many types of grinding sets of disk mills designed for the propagation of fibrous materials [1,2]. But all types of these disks are combined with a flat grinding surface and with fixed geometric characteristics: knife patterns, knife angles relative to the radius, the number of sectors that cannot be changed in the future during operation [3]. Disks with a complicated radial-axial profile of the contour of the cross section of the knife surface have a design of concentric rings mounted on the rotor and stator disks $[4,5]$. A wide range of modes of the trajectory of the fibrous material through the working knife cavity is achieved by giving concentric rings in the cross section of a different height rectangular shape [4]. The total working area of the rings is divided into sectors on which the mating protrusions are uniformly distributed, forming straight knives with a constant width and angle to one of the sides of the sector. Formed in a section along the knives, the lines of the working surface are broken straight lines, connecting the mating points of the rings from the entrance to the periphery in series. The sum of each pair of conjugated rings of the rotor and stator is constant, and its rings are interchangeable [4], Figure 1, 2, 3. 


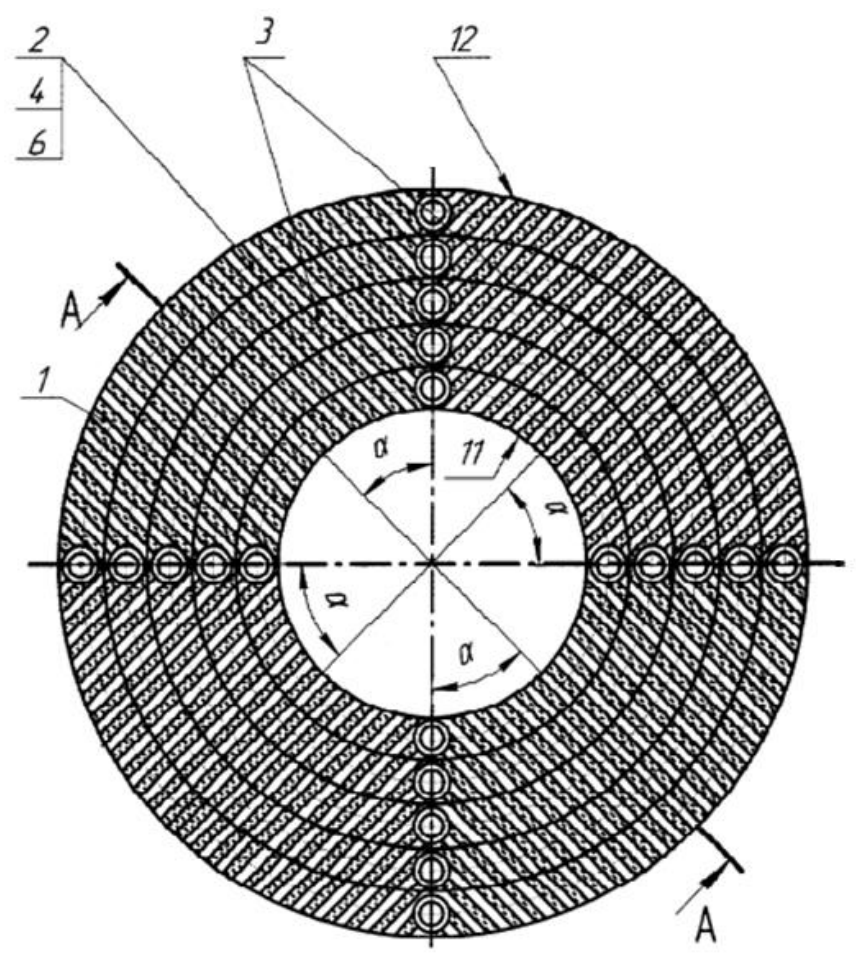

Figure 1. Set with a complicated radial-axial profile

1 - concentric rings ; 2 - protrusions; 3 - sectors; 4 - parallel knives; 6 - working surface;

11 - input circumferential edge; 12 - output circumferential edge

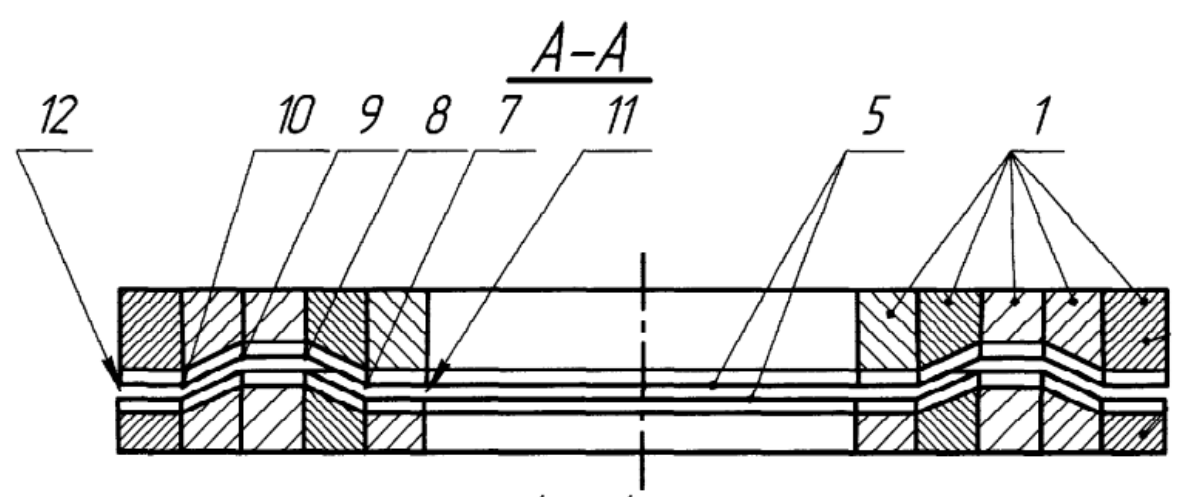

Figure 2. Set with wave-shaped grinding cavity

1 - concentric rings; 5 - line of working surfaces; 7-10 - interface points; 11 - input circumferential edge; 12 - output circumferential edge

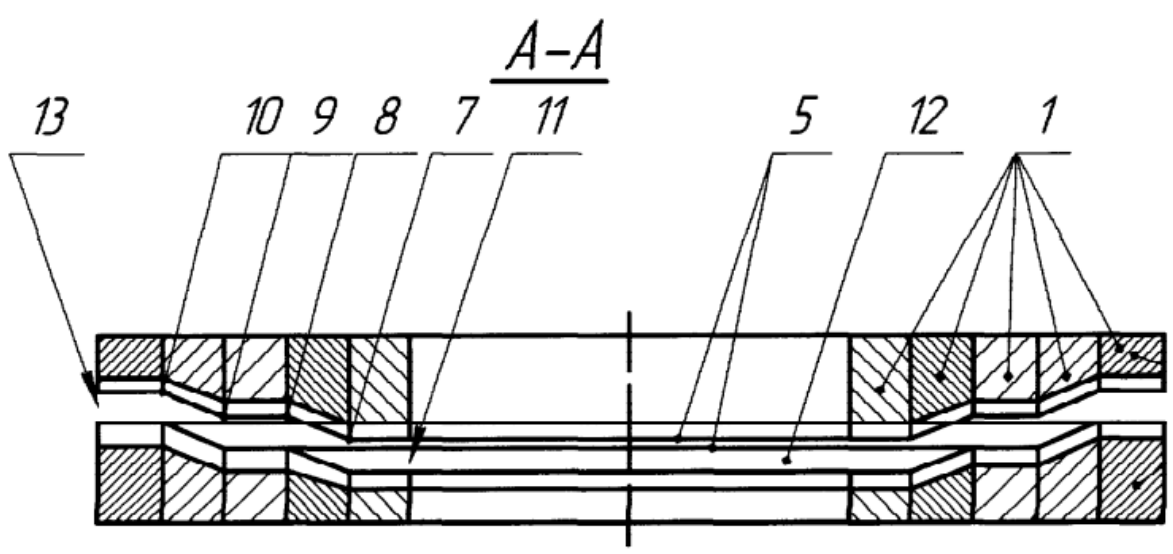

Figure 3. Conical grinding set

1 - concentric rings; 5 - line of working surfaces; 7-10 - interface points; 11 - input circumferential edge; 12 output circumferential edge; 13 - a pair of conjugated rings. 
From pairs of conjugated rings, two grinding cavities can be made up for one profile: conical and wave-shaped $[3,4]$. The degree of breakdown is 1.5 times higher compared to a set with a wavy male cavity. Physico-mechanical characteristics obtained from pulp treated for garrison with a conical interknife cavity [3].

In theory, you can make up $77.5 * 1016$ set combinations. This is possible due to the fact that:

- each of the 5 belts can be rotated $360^{\circ}$ in a circle;

- it is possible to make a conical or wave-shaped grinding cavity from concentric rings;

- the profile of the rotor disk of the grinding set does not have to repeat the profile of the stator disk.

Suppose:

- concentric rings of the rotor and stator can be rotated $1^{\circ}$ around its axis;

- concentric rings and stator can be rotated up to $90^{\circ}$, as well as from $90^{\circ}$ to $360^{\circ}$ the sector pattern will be repeated;

- the first belt is always at an angle.

Then all the possible options for a grinding set with a spatial arrangement of knives will be:
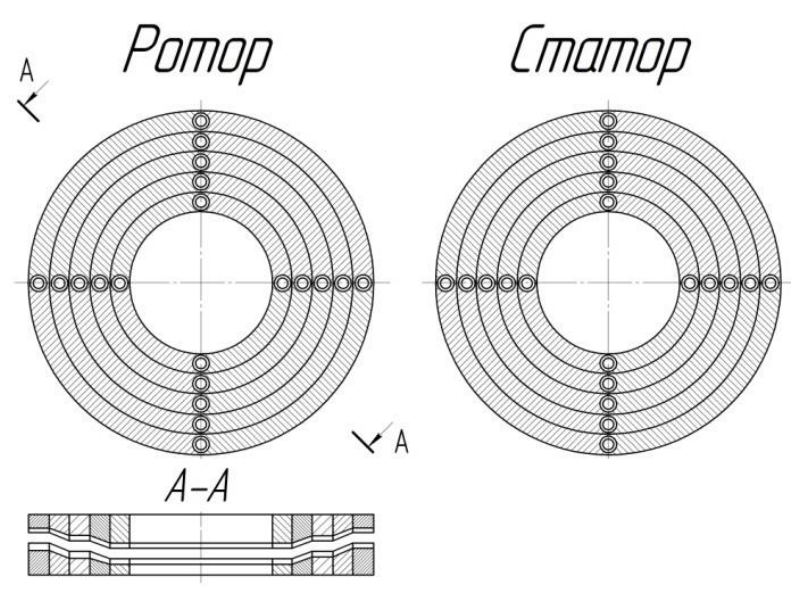

a)
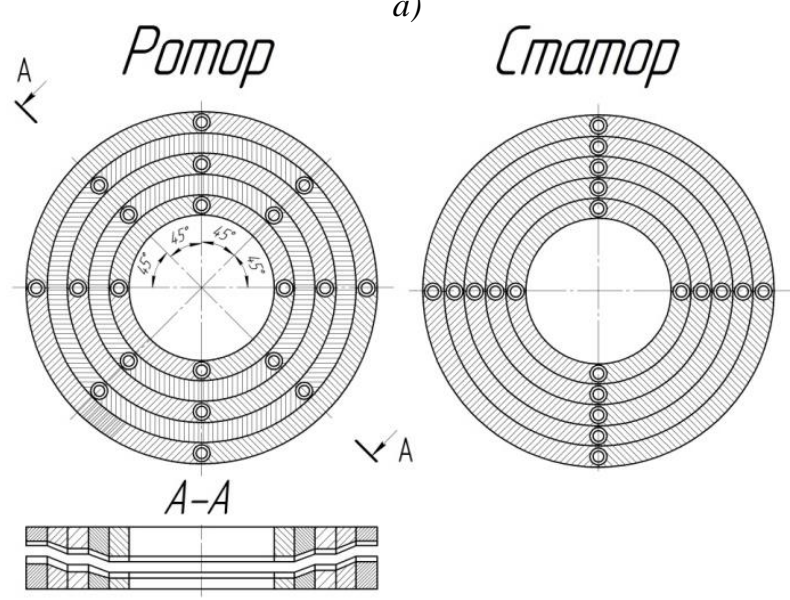

c)

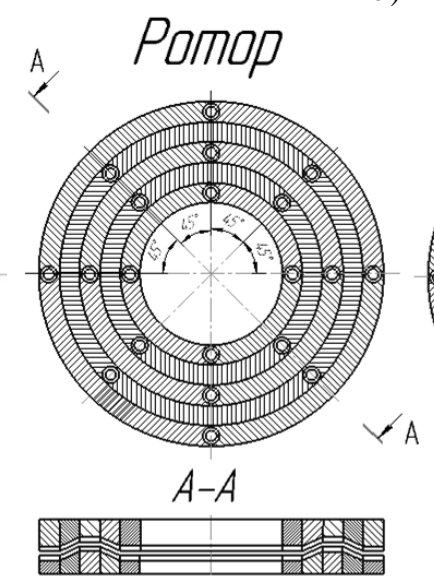

$$
\left(90^{4} * 90^{5}\right)=77,5 * 10^{16}
$$

For instance:

1) the concentric rings of the rotor and stator are not rotated relatively to each other, conical by the grinding cavity, Figure 4a;

2) the concentric rings of the rotor and stator are not rotated relatively to each other, wave-shaped by the reproduction cavity, Figure 4b;

3 ) the second and fourth concentric rings of the rotor from the center 0 of the ring 1 are rotated relative to the first, third and fifth by an angle of $45^{\circ}$, the concentric rings of the stator of the center 0 of the ring 1 are not rotated, the conical grinding cavity, Figure 4c;

4) the second and fourth concentric rings of the rotor from the center 0 of the ring 1 are rotated relative to the first, third and fifth by an angle of $45^{\circ}$, the concentric rings of the stator of the center 0 of the ring 1 are not rotated, a wavy grinding cavity, Figure 4d;
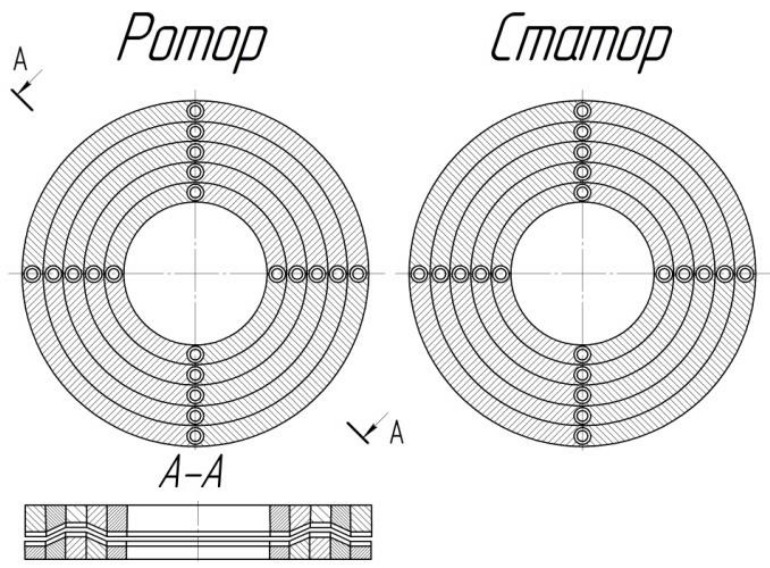

b)

Emamop

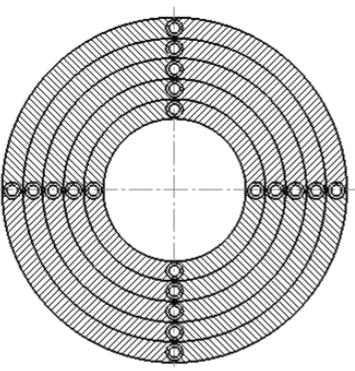

d)

Figure 4 - installation options for concentric rings of the rotor and stator.

The question remains open about the influence of the radially axial profile of the grinding set on the quality characteristics of the finished product.

\section{References}

1. Patent №2670523 Rossijskaja Federacija, MPK 51 B02C 7/12, D21D 1/30. Razmalyvajushhaja garnitura dlja diskovoj mel'nicy / Alashkevich Ju. D., Kovalev V. I.; zajavitel' i patentoobladatel': SibGU imeni M. F. Reshetneva № 2017141364, zajavl. 27.11.2017; opubl. 23.10.2018, Bjul. № 30. - $10 \mathrm{~s}$.

2. Patent № 2556534 Rossijskaja Federacija, MPK 51 B02C 7/12. Razmalyvajushhaja garnitura dlja diskovoj mel'nicy / Alashkevich Ju. D., Kovalev V. I., 
Shurkina V. I.; zajavitel' i patentoobladatel': Sibir. gosud. tehnolog. un-t № 2014103760/12, zajavl. 04.02.2014; opubl. 10.07.2015 Bjul. № 19. - 9 s.

3. M. A. Karbyshev, Ju. D. Alashkevich, A. A. Nabieva Vlijanie geometricheskogo postroenija nozhevoj garnitury na process obrabotki voloknistoj suspenzii // Vestnik gosudarstvennogo ajerokosmicheskogo universiteta imeni akademika M. F. Reshetneva. 2006. № 5. 123-127.

4. Patent № 2314380. Rossijskaja Federacija, MPK 51 D21D1/30, B02C 7/12. Razmalyvajushhaja

УДК 004

ГРНТИ 16.31.21 garnitura diskovoj mel'nicy / Alashkevich Ju. D., Kovalev V. I., Karbyshev M. A., Kozhuhov V. A., Baranovskij V. P.; zajavitel' i patentoobladatel': Sibir. gosud. tehnolog. un-t № 2006121708/12, zajavl. 19.06.2006; opubl. 10.01.2008, Bjul. № 1. - 5 s.

5. Ju. D. Alashkevich, V. I. Kovalev, A. A. Nabieva Vlijanie risunka garnitury na process razmola voloknistyh polufabrikatov: Monografija v 2-h chastjah. Chast' 1 / Ju.D. Alashkevich, V.I. Kovalev, A.A. Nabieva. Krasnojarsk: SibGTU, 2010. - 168 s.

\title{
СРАВНЕНИЕ АЛГОРИТМОВ ТЕМАТИЧЕСКОГО МОДЕЛИРОВАНИЯ ПРИ ОПРЕДЕЛЕНИИ ТЕМАТИК ПОСТОВ ЛЮДЕЙ В СОЦИАЛЬНОЙ СЕТИ “ВКОНТАКТЕ”
}

\author{
Черкасов Е.И. \\ Черкасов Егор Игоревич-магистрант, \\ Институт информационных технологий, \\ Челябинский Государственный Университет, г. Челябинск
}

\section{COMPARISON OF TOPIC MODELING ALGORITHMS IN DETERMINING THE TOPICS OF PEOPLE'S POSTS ON THE SOCIAL NETWORK "VKONTAKTE"}

Cherkasov E.I.

Cherkasov Egor Igorevich - undergraduate, Institute of Information Technologies,

Chelyabinsk State University, Chelyabinsk

\section{АННОТАЦИЯ}

В статье исследуется определение тематик текстов постов людей в социальной сети “Вконтакте". Дано описание тематического моделирования, описаны базовые модели векторного представления слов. Проведено сравнение моделей LDA, PLSA, ARTM при определении тематик текстов постов. Проведенные эксперименты показали, что лучше всего с этой задачей справляется модель ARTM.

\section{ABSTRACT}

The article examines the definition of topics of texts of posts of people in the social network "Vkontakte". A description of topic modeling is given, basic models of vector representation of words are described. A comparison of the LDA, PLSA, ARTM models in determining the topics of the text of the posts. The experiments showed that the ARTM model handles this task best.

Ключевые слова: тематическое моделирование, социальная сеть

Keywords: topic modeling, social network

\section{Введение}

Развитие интернета и появление социальных сетей привело к тому, что в свободном доступе появилось большое количество персональных данных: социально-демографические признаки, информация об уровне дохода и интересах, фото-, видео-, аудиоматериалы, заметки о путешествиях и т.д. Благодаря этому появилась возможность решать различные задачи, многие из которых до этого невозможно было решить из-за недостатка данных.

В России и странах СНГ большой популярностью пользуется социальная сеть “Вконтакте". Ежедневно пользователи создают миллионы постов и оставляют миллиарды комментариев, поэтому для многих компаний встает задача собрать эти данные, проанализировать и получить полезную информацию. Например, это может быть полезно для контроля имиджа компании (анализ уровня внимания и лояльности к бренду, выявление угроз репутации компании), повышения эффективности PR-кампаний (выявление лидеров мнений и важных тематических сообществ, оценка эффективности разовых $\mathrm{PR}$-мероприятий), улучшения продуктов и услуг (выявление характеристик продукта значимых для целевой аудитории, оперативное выявление технических проблем с продуктом), повышения качества обслуживания и лояльности клиентов (мониторинг обратной связи от клиентов, помощь клиентам в удобных для них каналах связи) и другом.

Для большинства этих задач необходимо анализировать текст. Методы обработки естественного языка сейчас активно развиваются. В том числе активно развивается тематическое моделирование - метод, который позволяет выделить темы из большой текстовой коллекции. 